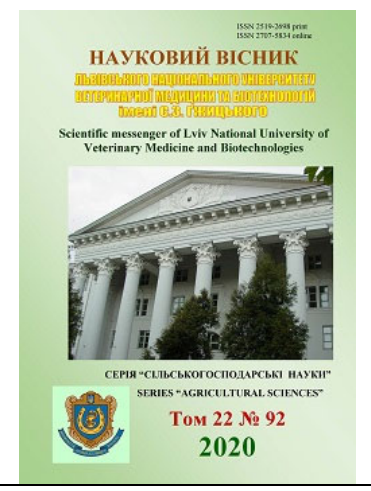

Науковий вісник Дьвівського національного університету ветеринарної медицини та біотехнологій імені С.3. Гжицького. Серія: Сільськогосподарські науки

Scientific Messenger of Lviv National University of Veterinary Medicine and Biotechnologies. Series: Agricultural sciences doi: 10.32718/nvlvet-a9215

https://nvlvet.com.ua/index.php/agriculture

UDC 504.453(477.43)

\title{
Analysis of water-ecological problems of Khmelnytsk region
}

\author{
B. M. Kalyn, S. A. Nepytaliuk
}

Stepan Gzhytskyi National University of Veterinary Medicine and Biotechnologies Lviv, Ukraine

Article info

Received 12.02.2020

Received in revised form 12.03.2020

Accepted 13.03.2020

Stepan Gzhytskyi National University of Veterinary Medicine and Biotechnologies Lviv, Pekarska Str., 50, Lviv, 79010, Ukraine. Tel.: +38-096-289-52-40 E-mail: dana24b@ukr.net
Kalyn, B. M., \& Nepytaliuk, S. A. (2020). Analysis of water-ecological problems of Khmelnytsk region. Scientific Messenger of Lviv National University of Veterinary Medicine and Biotechnologies. Series: Agricultural sciences, 22(92), 87-92. doi: 10.32718/nvlvet-a9215

At the present stage, in the conditions of growing scale of anthropogenic impact on water resources, shortage of quality drinking water and climate change, priority measures should be their rational use and comprehensive conservation. The article analyzes the environmental problems of surface waters of river basins, analyzed the existing potential of water resources and the state of water use, qualitative and quantitative indicators of surface waters of river basins of the Dnieper, Southern Bug and Dniester within Khmelnytsky region. The main problems of water resources of the region are highlighted and proposals for their effective use are formulated. A feature of the Khmelnytsky region is its location in three river basins - the rivers Dniester, Southern Bug and Dnieper. The main share of water intake in the region comes from surface objects, and s unevenly distributed throughout its territory. The study shows that in the sectoral structure of general use of water in Khmelnytsky region, the largest consumer is industry (58.6\%), and among industries electricity sector is the main and largest consumer. The main environmental problem of the region is the pollution of surface water bodies with untreated and insufficiently treated return water. In the territory of Khmelnytsky region, 80 water users discharge return water into water bodies. The average annual concentrations of manganese (2-6 times), copper (4-7 times) and nitrites (2-5 times) were exceeded in all control samples from water bodies of Khmelnytsky region. There is also an increase in the total amount of discharges of pollutants, including petroleum products, suspended solids, sulfates, total iron, and copper. In addition to pollution, the problem is the current structure of land within river basins. Excessive plowing is one of the main negative factors that contributes to the deterioration of the water regime and leads to pollution of water bodies. Within the Khmelnytsky region, arable land is the dominant form of land use, their share is 50-70\%. Restoration of the quality of water bodies involves the implementation of measures to reduce the environmental risk of deterioration based on the analysis of the impact of anthropogenic factors and a set of water protection measures.

Key words: water resources, surface water, river basin, water service, drainage, pollution, a source of pollution, quality of water, landscape structure.

\section{Аналіз водогосподарсько-екологічних проблем Хмельницької області}

\author{
Б. М. Калин, С. А. Непиталюк
}

Львівський національний університет ветеринарної медицини та біотехнологій імені С. 3. Гљсицького, м. Львів, Україна

На сучасному етапі в умовах зростаючих масштабів антропогенного впливу на водні ресурси, дефіциту якісної питної води та кліматичних змін першочерговими заходами повинно бути їхнє раціональне використання та всебічне збереження. У статті здійснено аналіз екологічних проблем поверхневих вод річкових басейнів, проаналізовано наявний потенціал водних ресурсів та стан водокористування, якісні та кількісні показники поверхневих вод річкових басейнів Дніпра, Південного Бугу та Дністра у межах Хмельницької області. Виокремлено найбільші проблеми водних ресурсів області та сформульовано пропозиції шчодо їх ефективного використання. Особливістю Хмельницької області є ї̈ розташування у трьох водозбірних басейнах - річок Дністра, Південного Бугу та Дніпра. Основна частка водозабору області відбувається з поверхневих об 'єктів і нерівномірно розподіляється по ї̈ території. В дослідженні показано, щу в галузевій структурі загального використання води в Хмельницькій області найбільщим ї̈ 
споживачем є промисловість (58,6\%), а серед галузей промисловості основним і найбільшим водоспоживачем є електроенергетика. Основною екологічною проблемою області є забруднення поверхневих водних об'єктів неочищеними і недостатньо очищеними зворотними водами. На території Хмельницької області скид зворотних вод у водні об'єкти здійснюють 80 водокористувачів. У всіх контрольних створах водних об 'єктів Хмельницької області відмічено перевищення середньорічних концентрацій Марганцю (у 2-6 разів), Міді (у 4-7 разів) та нітритів (у 2-5 разів). Спостерігається збільшення також сумарної кількості скидів забруднюючих речовин, зокрема нафтопродуктів, завислих речовин, сульфатів, Заліза загального і Міді. Окрім забруднення, проблемою є діюча структура земельних угідь у межах річкових басейнів. Надмірна розораність є одним з основних негативних чинників, цио впливає на погіршення водного режиму та призводить до забруднення водних об'єктів. В межах Хмельницької області орні землі виступають домінуючою формою землекористування, їхня частка становить 50-70 \%. Відновлення якісного стану водних об'єктів передбачає здійснення заходів щодо зменшення екологічного ризику погіршення їх стану на основі аналізу впливу антропогенних чинників та проведення комплексу водоохоронних заходів.

Ключові слова: водні ресурси, поверхневі води, річковий басейн, водозабезпечення, водовідведення, забруднення, джерело забруднення, якість води, ландшафтна структура.

\section{Вступ}

Антропогенний вплив на навколишнє природне середовище викликає як зміну стану окремих його компонентів, так і трансформацію екосистеми загалом, викликаючи порушення іiї внутрішньої структури і функціонування.

Басейн річки $є$ індикатором стану навколишнього середовища, що зумовлюється сукупною дією природних просторово-часових, кліматичних, гідрологічних, грунтово-рослинних, геолого-геоморфологічних та інших чинників (Iatsyk et al., 2018).

У міру зростання антропогенних навантажень на річковий басейн відбувається перетворення природної системи на нову - природно-господарську. Також змінюються і темпи цих перетворень: зі збільшенням навантажень на водні об'єкти негативні незворотні зміни відбуваються швидко і стосуються всіх складових водної екосистеми (Zhuk, 2019). Основними антропогенними чинниками, що впливають на погіршення кількісних та якісних показників водних ресурсів, є розораність, урбанізованість, забір води, скидання стічних вод (Paraniak et al., 2014; Zhuk, 2019).

Для визначення комплексу природоохоронних заходів необхідно визначити вплив природних і антропогенних чинників на екологічний стан річок та проаналізувати раціональність господарського використання водозбірної площі річкового басейну.

Метою досліджень було визначити основні водогосподарсько-екологічні проблеми річкових басейнів в межах Хмельницької області.

\section{Результати та їх обговорення}

Водні ресурси Хмельницької області складаються 3 поверхневого стоку (в середньому 2,1 млрд м $^{3} /$ рік) і

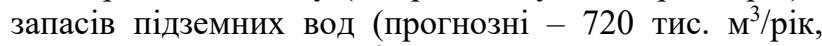
затверджені - 160 млн м³/рік).

Особливістю Хмельницької області є їі розташування у трьох водозбірних басейнах. Річкова сітка Хмельницької області представлена басейнами Дністра (займає 7,74 тис. км², або 37,6 \% території), Південного Бугу (4,61 тис. км², або 22,4 \%) і Дніпра (8,27 тис. км², або $40 \%$ території області). Гідрографічна сітка області нараховує 3733 водотоків загальною довжиною 12880 км, в тому числі великі річки: Дністер (в межах області 152 км) і Південний Буг (140 км); середні річки: Случ (119 км), Горинь (150 км), Збруч (247 км), а також 3728 малих річок i водотоків загальною довжиною 12072 кілометрів. Річок довжиною понад 10 км виявилося 211 (в т. ч. малих 206) загальною довжиною 4872 км (в т. ч. малих 4064 км) (Hovorun \& Tymoshchuk, 2010; Rehionalnyi ofis vodnykh resursiv u Khmelnytskii oblasti).

Озер в області дуже мало, і вони невеликі за розмірами та розташовані в основному в лісових масивах. На півночі області у басейні Горині - найбільші озера Святе та Теребіж, площа водного дзеркала яких відповідно 4,2 і 2,6 га.

Уся річкова система області зарегульована великою кількістю водосховищ та ставків. На території області є 52 водосховища, в тому числі 1 міжобласне - Дністровське водосховище. Більшість водосховищ мають об'єм менше ніж 10 млн м ${ }^{3}$, і лише два 3 них Щедрівське i водойма-охолоджувач Хмельницької атомної електростанції (ХАЕС) мають повний об'єм 25,2 і 120 млн м ${ }^{3}$ відповідно. На території області 2709 штучних водних об'єкти (ставки), загальною площею 17,38 тис. га, з яких 1633 в оренді, загальною площею 12,75 тис. га.

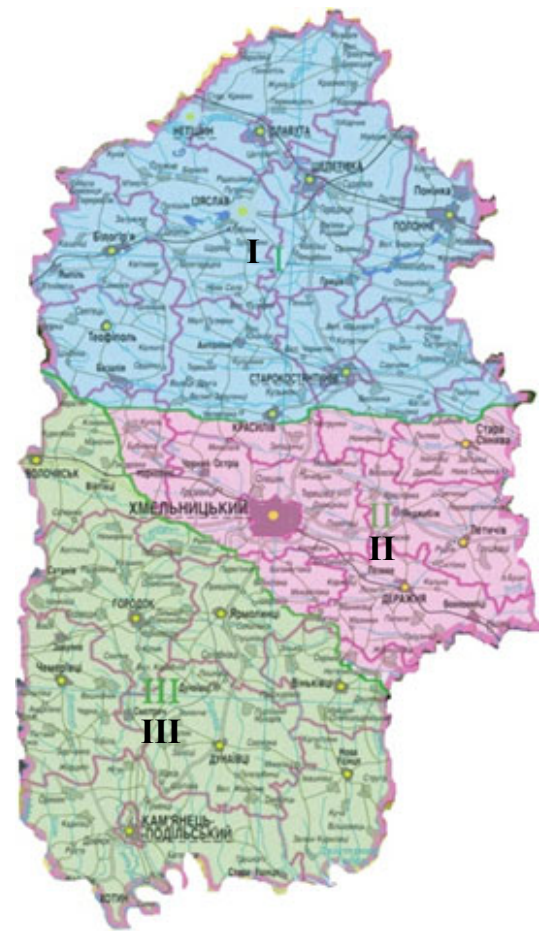

Рис. 1. Річкова мережа Хмельницької області (Rehionalnyi ofis vodnykh resursiv u Khmelnytskii oblasti) Примітка: I Басейн Дніпра; II Басейн Південного Бугу; III Басейн Дністра 
Сумарний питомий показник забезпеченості населення Хмельницької області водними ресурсами в середньоводний рік становить 7,906 тис. м³ на рік на 1 особу (Obukhov, 2019).

На території Хмельницької області водозабір відбувається як 3 поверхневих водних об'єктів, так і 3 підземних. Основна частка водозабору відбувається 3 поверхневих об'єктів і в середньому складає близько 60 \% від загального водозабору. У 2018 р. $з$ поверхневих водних об'єктів забрано 58,15 млн м ${ }^{3}$ води, що на $12,2 \%$ менше порівняно 3 попереднім роком. Найбільші об'єми забору поверхневої води здійснюють ВП “Хмельницька АEC”, орендарі ставків (переважно весною), цукрозаводи (переважно восени), ПАТ “Подільський цемент” (м. Кам'янець-Подільський).

Об'єм забраної води нерівномірно розподіляється по території області (рис. 2). На це впливає забезпеченість адміністративних районів області водними ресурсами та розвиток різноманітних галузей промисловості. У розрізі річкових басейнів найбільший забір води, зокрема і поверхневої, здійснюється у басейні Дніпра - 68,6 \% та 62,0 \% відповідно. Це зумовлено розташуванням в межах басейну промислових підприємств $з$ високим показником водозабору. Лише у Красилівському районі, 3/4 території якого належить до басейну Дніпра, загальний показник забраної води становить понад 20 млн м².

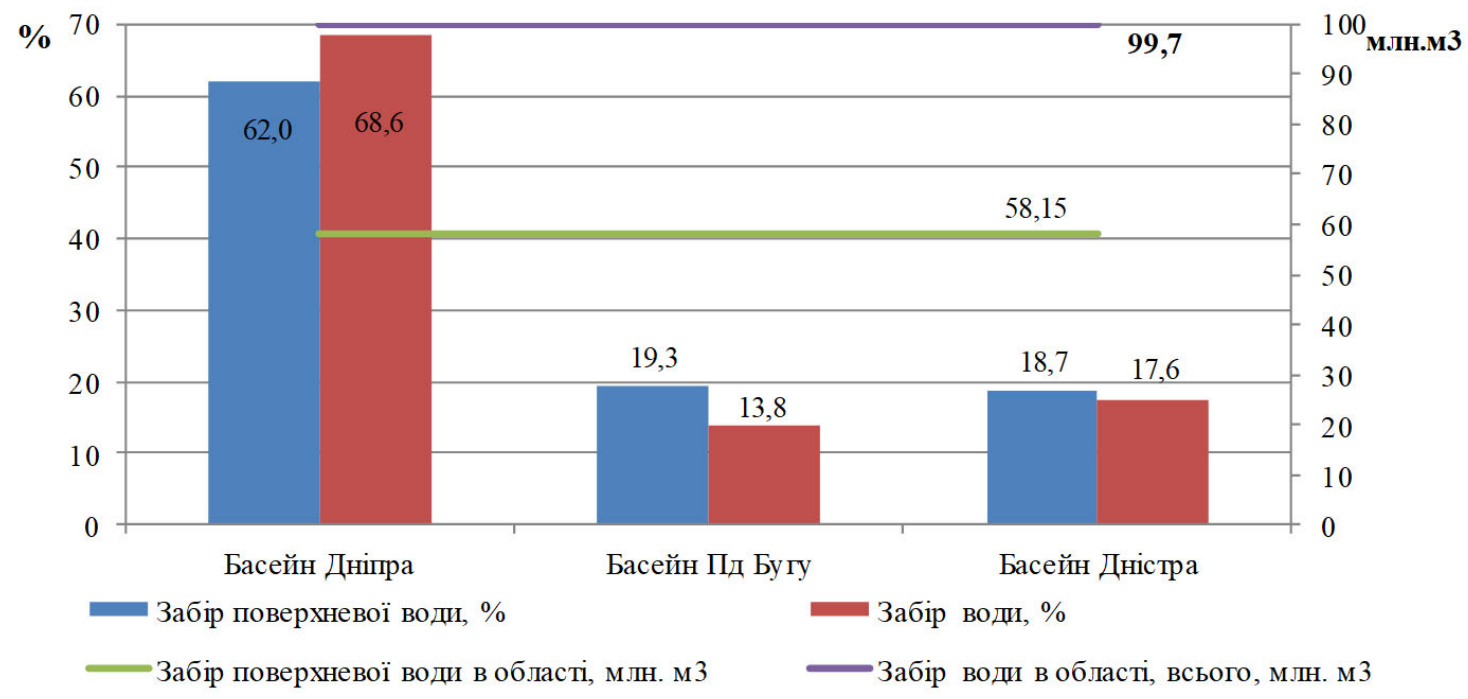

Рис. 2. Водозабір із природних джерел у 2018 році

Об’єм використаної води в межах річкових басейнів є меншим від об'єму забраної води. Це пояснюється втратами води при транспортуванні, які становлять понад $10 \%$.

Домінуючими галузями забору води в Хмельницькій області $\epsilon$ промисловість та комунальне господарство, на які припадає 58,6 \% і 38,8 \%. Використання свіжої води у межах області на сільськогосподарські потреби становить 2,4 \%, а найменшу кількість води використовують при зрошенні - менше ніж 1 \%. Розподіл обсягів використання води різними галузями економіки в розрізі річкових басейнів подано на рис. 3. Як було з'ясовано вище, в басейні Дніпра переважає використання води на виробничі потреби, зокрема для потреб електроенергетики. В басейні Дністра, навпаки, високий відсоток використання води на господарсько-питні цілі.
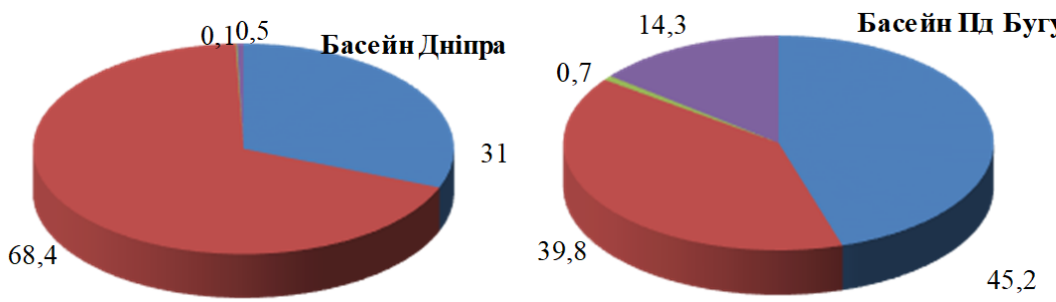

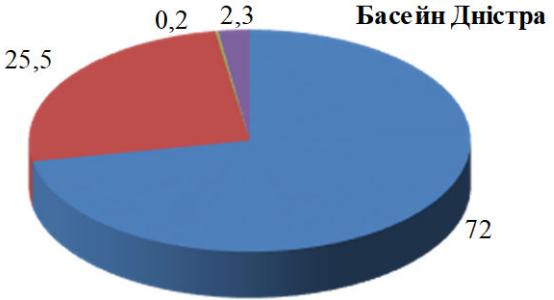

Рис. 3. Діаграми водокористування в розрізі річкових басейнів в межах Хмельницької області, \%

Головними чинниками погіршення якості поверхневих і грунтових вод річкових басейнів є скиди стічних вод. Унаслідок господарського використання у поверхневі водні об'єкти Хмельницької області скидались зворотні забруднені води, нормативно чисті без очистки та нормативно очищені на очисних спорудах. На території області скид зворотних вод у вод- ні об'єкти здійснюють 80 водокористувачів. Повна біологічна очистка 3 подальшим скидом очищених стічних вод у водні об'єкти здійснюється на 54 комплексах очисних споруд.

Загальний об'єм скинутих зворотних вод становив 49,98 млн м ${ }^{3}$, $з$ них 47,38 млн м ${ }^{3}-$ у поверхневі водні об'єкти. Найбільше скинуто нормативно очищених 
вод на очисних спорудах - 30,14 млн м³, з яких найбільше в межах басейну Південного Бугу. Кількість зворотних вод, скинутих у поверхневі водні об'єкти басейну Південного Бугу у межах області становить $58,3 \%, 38 \%$ та $18 \%$ відповідно нормативно очище- них, нормативно чистих та забруднених вод від кожної категорії скидів по області. Для поверхневих водних об'єктів в басейні Дніпра та Дністра аналізовані показники відповідно становлять $31 \%, 46,3 \%, 50,8$ \% та $10,7 \%, 15,7 \%, 31,2 \%$ (рис. 4).

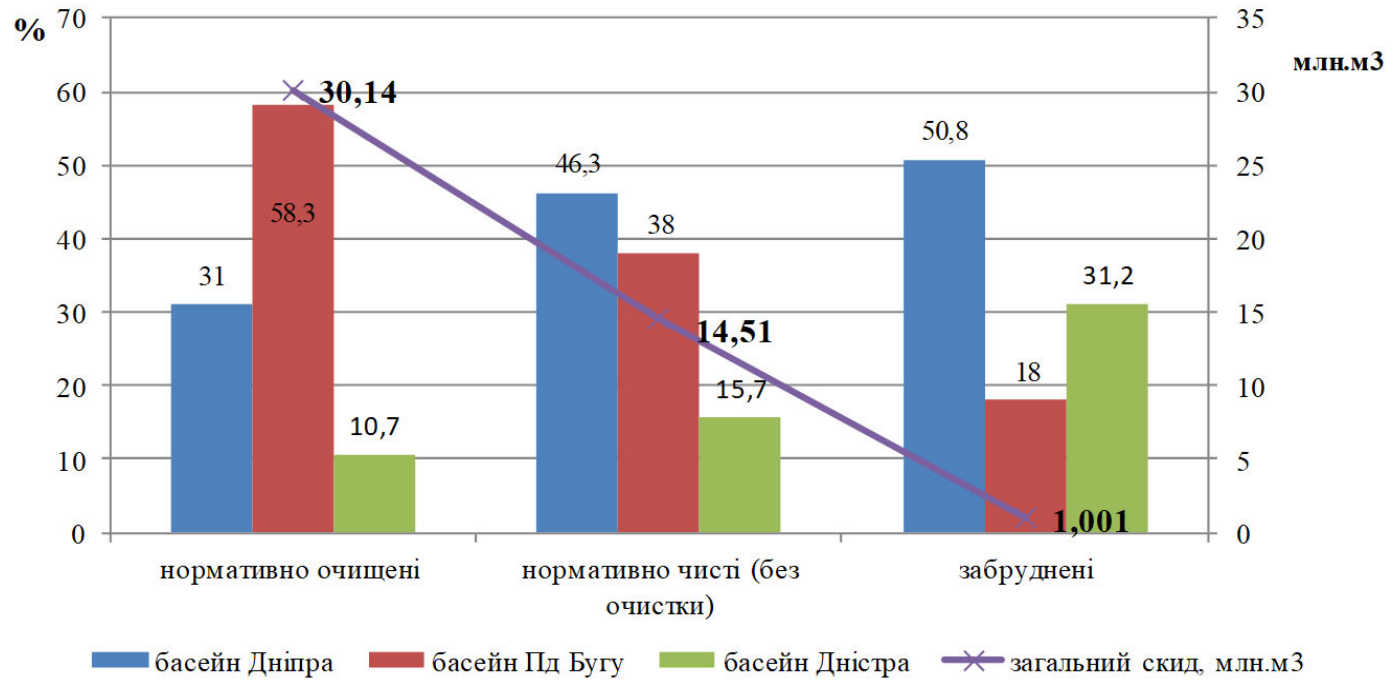

Рис. 4. Скид зворотних вод у поверхневі водні об’єкти Хмельницької області

Загальний вміст забруднюючих речовин, скинутих у складі зворотних вод у поверхневі водні об'єкти Хмельниччини у 2018 році становив 21,366 тис. т. Найбільшою небезпекою для поверхневих вод $є$ надходження в річки органічних, біогенних, токсичних синтетично-активних речовин, нафтопродуктів, важких металів.

У 2018 році скиди забруднюючих речовин, які визначені державною звітністю за формою № 2ТП- водгосп (річна), збільшились: по нафтопродуктах $+0,149$ т, завислих речовинах $+6,0$ т, сульфатах $+6,0$ т, Залізу загальному $+0,065$ т, Міді $+0,037$ т. Проте зменшились по сухому залишку $-390,0$ т, БСК5 -10,0 т, хлоридах $-53,0$ т, азоту амонійному $-2,0$ т, нітратах $-4,0$ т, фосфатах -9,09 тонни (Rehionalna dopovid, 2018). У розрізі річкових басейнів обсяги скидів забруднюючих речовин показано в табл. 1 .

\section{Таблиця 1}

Кількість забруднюючих речовин, скинутих у складі зворотних вод в поверхневі водні об’єкти Хмельницької області (Rehionalna dopovid, 2018)

\begin{tabular}{lcccc}
\hline \multicolumn{1}{c}{ Забруднюючі речовини } & \multirow{2}{*}{ Всього } & \multicolumn{3}{c}{ В тому числі: } \\
\cline { 3 - 5 } БСК5, тис. т & 0,370 & басейн Дніпра & басейн Пд Бугу & басейн Дністра \\
\hline Нафтопродукти, т & 1,221 & 0,087 & 0,174 & 0,109 \\
Завислі речовини, тис. т & 0,371 & 0,367 & 0,826 & 0,028 \\
Сухий залишок, тис. т & 16,30 & 0,111 & 0,184 & 0,075 \\
Сульфати, тис. т & 1,801 & 2,882 & 8,841 & 4,579 \\
Хлориди, тис. т & 1,986 & 0,345 & 0,823 & 0,633 \\
Азот амонійний, тис. т & 0,101 & 0,444 & 0,908 & 0,635 \\
Нітрати, тис. т & 0,318 & 0,017 & 0,049 & 0,034 \\
Нітрити, тис. т & 0,024 & 0,046 & 0,090 & 0,182 \\
ХСК, т & 1,667 & 0,001 & 0,017 & 0,006 \\
Фосфати, т & 80,88 & 0,447 & 0,872 & 0,348 \\
Залізо, т & 6,096 & 16,34 & 50,09 & 14,46 \\
Мідь, т & 0,244 & 1,980 & 3,407 & 0,709 \\
СПАР, т & 4,718 & 0,152 & 0,083 & 0,009 \\
\hline
\end{tabular}

Варто відзначити зростаюче антропогенне навантаження на поверхневі води басейну Південного Буг в межах Хмельницької області. Питуляк М. та ін. (Pytuliak \& Pytuliak, 2019) пов'язують це зі значною зміною кліматичних умов, маловодністю та зарегульованістю ріки, наявністю підприємствзабруднювачів - Наркевицького цукрового заводу,
МКП “Хмельницькводоканал” та інших, ставків 3 інтенсивною технологією вирощування риби. Особливо гостро вплив забруднювачів проявляється на ділянках водотоки, що зазнають впливу стічних вод міст та населених пунктів, які є сумішшю промислових та господарсько-побутових стічних вод та основним джерелом забруднення вод сполуками Азоту i 
Фосфору. Зростання концентрацій зазначених речовин призводить до евтрофікації природних вод, яка проявляється у збільшенні біомаси фітопланктону, масовому розвитку водоростей та “цвітінні” води, що погіршує екологічний стан та якість природних вод (Iefremova et al., 2018).

На рис. 5 схематично показано стан поверхневих вод річкових басейнів за даними моніторингу лабораторії вод та грунтів РОВР у Хмельницькій області. У всіх контрольних створах басейну Дніпра спостерігалися перевищення ГДК забруднюючих речовин до 3 разів за 6 показниками. Щодо показників якості води у створах басейну Південного Буг, то їхня кількість та кратність перевищень була різною. Найбільші перевищення виявляли у створах біля с. Копистин, нижче м. Хмельницького та у Меджибізькому водосховищі. Найменшу кількість та кратність перевищень ГДК забруднюючих речовин зафіксовано у створі біля с. Цвіклівці (питний водозабір для м. Кам'янеця-

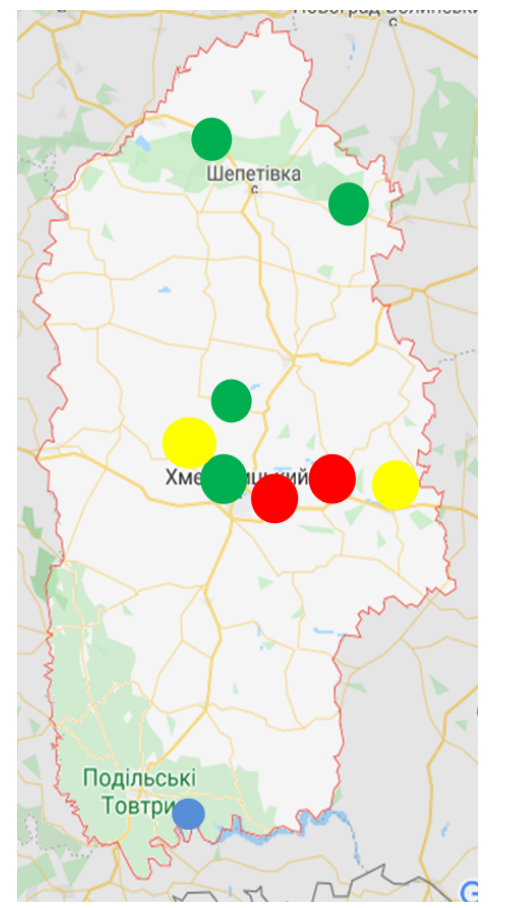

Рис. 5. Екологічна оцінка водних ресурсів Хмельницької області (Ekolohichnyi pasport Khmelnytskoi oblasti za 2018 r)

\section{Висновки}

На основі проведеного аналізу встановлено, що обсяг водозабору в Хмельницькій області, структура водокористування, а також кількісні та якісні показники скиду зворотних вод у водні об'єкти різняться в межах річкових басейнів.

Збереження екологічного потенціалу водних ресубезпечного водокористування в річкових басейнах, проведення комплексного моніторингу 3 інтегральною оцінкою екологічного стану досліджуваних об'єктів, встановлення нормативів ГДС з урахуванням пріоритетних показників якості води, ідентифікацією водоохоронних зон, впровадженням водозберігаючих та безводних технологій. рсів потребує удосконалення раціонального еколого-
Подільського) на р. Дністер. У всіх контрольних створах водних об'єктів Хмельницької області спостерігали перевищення середньорічних концентрацій Марганцю (у 2-6 разів), Міді (у 4-7 разів) та нітритів (у 25 разів).

Для річкових басейнів України характерним є порушення ландшафтної структури водозбірної площі 3 перевагою нестабільних елементів ландшафту - ріллі. Так, в межах Хмельницької області у 17-ти фізикогеографічних районах вона займає понад 50 \% загальної земельної площі. У межах 11-ти районів частка перевищує $60 \%$, а в чотирьох - понад $70 \%$ (Kasiianyk, 2011). Саме надмірна розораність є одним 3 основних негативних чинників, бо інтенсивне землеробство без достатніх грунтозахисних заходів впливає на зміни водного режиму річок, посилює ерозійні процеси, порушує морфологічну систему та руслові процеси, призводить до забруднення водних об'єктів.

Кратність перевищення норм, рази

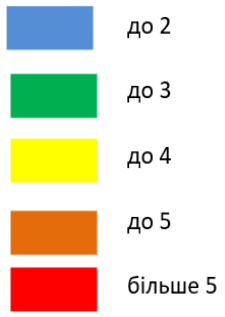

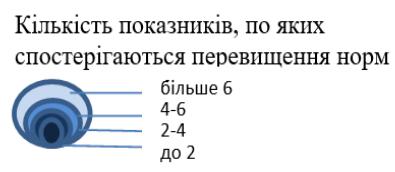

References

Ekolohichnyi pasport Khmelnytskoi oblasti za 2018 r. [Elektronnyi resurs] Rezhym dostupu: https:/www.adm-km.gov.ua/?page_id=7157 (in Ukrainian).

Hovorun, V., \& Tymoshchuk, O. (2010). Richky Khmelnychchyny. Navchalnyi posibnyk. Vydannia druhe. Khmelnytskyi: Polihrafist (in Ukrainian).

Iatsyk, A. V., Pasheniuk, I. A., Hopchak, I. V., \& Basiuk, T. O. (2018). Vodohospodarsko-ekolohichni problemy richok Zakhidnoho Polissia Ukrainy (na prykladi baseinu richky Horyn). Visnyk ahrarnoi nauky, 96(10), 61-65. doi: 10.31073/agrovisnyk201810-09 (in Ukrainian). 
Iefremova, O. O., Mironova, N. H., Mateiuk, O. P., Diachuk, A. O., \& Shevchenko, S. M. (2018). Ekolohohihiienichna otsinka stanu r. Pivdennyi Buh u mezhakh Khmelnytskoi oblasti za period 2013-2017 rr. Visnyk Khmelnytskoho natsionalnoho universytetu. Tekhnichni nauky, 5, 261-266. Rezhym dostupu: http://nbuv.gov.ua/UJRN/Vchnu_tekh_2018_5_43 (in Ukrainian).

Kasiianyk, I. (2011). Landshaftno-konturna optymizatsiia zemlekorystuvannia na prykladi Kormylchanskoi silskoi rady. Naukovi zapysky Ternopilskoho natsionalnoho pedahohichnoho universytetu imeni Volodymyra Hnatiuka. Ser. Heohrafiia, 2(30), 232 237. http://nbuv.gov.ua/UJRN/NZTNPUg_2011_2_42 (in Ukrainian).

Obukhov, Ye. V. (2019). Pokaznyky zabezpechenosti naselennia Ukrainy vodnymy resursamy na pochatku 2019 roku. Hidroenerhetyka Ukrainy, 1-2, 31-35. https://uhe.gov.ua/sites/default/files/2019-08/10.pdf (in Ukrainian).
Paraniak, R. P., Voitovych, N. V., Kalyn, \& B. M. (2014). Systema upravlinnia vodnymy resursamy u Lvivskii oblasti. Nauk. visnyk LNUVMBT imeni S.Z. Gzhytskoho, 16, 3(60), 386-393. (in Ukrainian).

Pytuliak, M., \& Pytuliak, M. (2019). Suchasnyi stan ta osoblyvosti vykorystannia vodnykh resursiv Khmelnytskoi oblasti. Naukovi zapysky Ternopilskoho natsionalnoho pedahohichnoho universytetu imeni Volodymyra Hna-tiuka. Ser. Heohrafiia. Ternopil: TNPU im. V. Hnatiuka, 47(2), 156-163. http://nzg.tnpu.edu.ua/article/view/184999 (in Ukrainian).

Rehionalna dopovid "Stan navkolyshnoho pryrodnoho seredovyshcha u Khmelnytskii oblasti u 2018 rotsi". Khmelnytska ODA, Departament pryrodnykh resursiv ta ekolohii. Khmelnytskyi, 218 (in Ukrainian).

Rehionalnyi ofis vodnykh resursiv u Khmelnytskii oblasti [Elektronnyi resurs] Rezhym dostupu: https://rovrkhm.gov.ua (in Ukrainian).

Zhuk, V. (2019). Faktory antropohennoho i pryrodnoho vplyvu na stan richkovoho baseinu. Vodne hospodarstvo Ukrainy, 9-10, 47-49 (in Ukrainian). 